\title{
Regulatory and Institutional Context of Dangerous Goods Road Transport at the International, African and Moroccan Levels
}

\author{
Moncif Sabar*, Mohammed El Hammoumi \\ Laboratory of Industrial Techniques, Sidi Mohammed Ben Abdellah University, Faculty of Sciences \& Techniques, Fez 2202, \\ Morocco
}

Corresponding Author Email: moncif.sabar@usmba.ac.ma

https://doi.org/10.18280/ijsse.100213

Received: 10 October 2019

Accepted: 21 February 2020

\section{Keywords:}

chemicals, dangerous goods, international conventions, regulation, road transport

\begin{abstract}
International regulations for the Transport of Dangerous Goods (TDG), including chemicals are governed by the United Nations (UN) recommendations in the form of a model regulation and by international and regional agreements. This transportation may take place by road, rail, sea, river, air or multimodal transport. Through this state of the art, we will focus on the International, African and Moroccan regulatory and institutional context of the road transport of dangerous goods. Constraints in the regulation of the transport of dangerous chemical within the Moroccan territory are discussed in details with the view of highlighting prospects for improvement.
\end{abstract}

\section{INTRODUCTION}

Chemical and para-chemical industries occupy an important place in the international economy in general and Moroccan in particular by the diversity of their products and by the organic link which associates them to other economic activities upstream or downstream, especially the automobile, agri-food, housing and others. according to the French Federation of Road Transport, $15 \%$ of the world traffic concerns hazardous materials (all products and all modes of transport). Petroleum products account for $75 \%$, chemicals $20 \%$ and $5 \%$ for gas products [1]. Also, The European Statistical Office (Eurostat) provides relevant statistics on the annual road freight transport of dangerous goods, by type of dangerous goods and broken down by activity [2]. In order to allow the movement of dangerous goods between countries, the TDG regulation is designed to avoid human and material accidents as much as possible [3-5], prevent the degradation of the environment and check the deterioration of transport equipment [6]. The TDG is based on various international regulations, notably the European Agreement concerning the International Carriage of Dangerous Goods by Road (ADR Agreement) [7], the European Agreement concerning the International Carriage of Dangerous Goods by Inland Waterways (ADN Agreement) [8], the International Carriage of Dangerous Goods by Rail (RID Regulations) [9], the International Maritime Dangerous Goods Code (IMDG Code) [10] and the Technical Instructions of the International Civil Aviation Organization for the safe TDG by Air (ICAO Technical Instructions) [11]. Coherence between these different regulations is ensured by the UN, which maintains Globally Harmonized System of Classification and Labelling of Chemicals (GHS) [12] and a Model Regulations [13]. The latter serves as a basis for all the above-mentioned international regulations [1].

The TDG which is strictly associated with safety, security and environmental concerns has already been addressed by reviews. An older comprehensive literature survey can be found in Erkut and Verter [14], but the most important so far is the review of Erkut et al. [15] including over 170 articles. Then the survey conducted by Erol and Yilmaz [16] which reviews 179 articles from 1973 to 2014. A more recent literature survey by Holeczek [17] reviews over 300 publications from 1973 to 2017 and shows the historical development and points out recent trends. Research gaps and new potential challenges are identified. The regulatory framework for the TDG (including chemicals) has been reviewed by only a few studies, such as the publication of Imeri et al. [18].

In this paper, we give a general overview of the regulatory and institutional context of road transport of chemicals which are considered as dangerous goods at the international and African levels, while highlighting the Moroccan case as well as constraints and prospects for improvement.

\section{STATE OF THE ART}

\subsection{At the international level}

At the international level, the United Nations (UN) recommendations on the TDG are contained in the UN Model Regulations prepared by the Committee of Experts on the TDG of the UN Economic and Social Council (ECOSOC). This Model brings together a set of basic provisions to establish uniform national and international regulations applying to the various modes of transport, while leaving sufficient flexibility to adapt them to particular cases [13]. They are addressed to governments and international organizations dealing with the regulation of the transport of dangerous goods and do not apply to bulk transport by sea or inland navigation in bulk carriers or tankers, which is subject to special international or national rules [13]. In order to harmonize the international transport of dangerous goods in general and chemicals in particular, the UN has developed: I) 
a list of dangerous goods which classifies products according to their UN number (4-digit code) on the basis of their transport [12] and II) a Globally Harmonized System (GHS) whose recommendations are incorporated into the UN Model Regulations [13] and also in the international and European legal instruments governing the TDG. Among the legal instruments are: the IMDG Code [10], the ICAO Technical Instructions [11], the ADR agreement [7], the RID Regulations [9] and the ADN Agreement [8].

\subsection{In Europe}

Available European statistical data on TDG are collected in EUROSTAT database [2]. According to the study of Russo and Rindone [19], the TDG in Europe measured in terms of tkm [tonnes $* \mathrm{~km}$ ], represents $7.6 \%$ of total transport of goods; this percentage is $13.5 \%$ for rail, $5.2 \%$ for road and $20 \%$ for inland waterways.

In Europe, road TDG is governed by the ADR Agreement, signed in Geneva on September 30, 1957 under the auspices of the UN Economic Commission for Europe and entered into force on January 29, 1968 [7]. The Agreement itself was amended by the protocol amending Article 14, paragraph 3, done at New York on August 21, 1975, which entered into force on April 19, 1985 [7]. The ADR is an interstate agreement that does not prescribe a sanction or central authority for its application. In practice, roadside checks are carried out by the contracting parties and if the rules are violated, the national authorities can prosecute the offenders according to their domestic legislation. This agreement applies to transport operations carried out in the territories of at least two of the signatory parties to this agreement [7]. It stipulates that, except for certain excessively dangerous goods, other dangerous goods may be the subject of international carriage in road vehicles if the conditions imposed by Annex A of ADR for goods in question are met, in particular, for their packaging, labeling and the conditions imposed by Annex B of the Agreement concerning the construction, the equipment and the circulation of the vehicle carrying the goods in question, are fulfilled [7]. However, according to Article 4 of ADR, each Contracting Party shall retain the right to regulate or prohibit, for reasons other than safety during carriage, the entry of dangerous goods into its territory. Contracting Parties also retain the right to arrange, by bilateral or multilateral agreements, that certain dangerous goods which are prohibited from carriage by Annex A be internationally carried on their territories under certain conditions, or that dangerous goods authorized to be carried internationally according to Annex A be carried on their territories under conditions less stringent than those specified in Annexes A and B" [7]. These annexes have been adopted by all member states of the European Union (EU) and form the basis for the regulation of the road TDG within and between the member states (Directive 2008/68/EC of the European Parliament and of the Council of September 24, 2008 on the inland TDG, as amended). A number of nonEU countries have also adopted Annexes A and B of ADR as the basis for their national legislation [7].

The structure of the ADR Agreement is consistent with that of the UN recommendations on the TDG, the RID Regulations, the IMDG Code and the Model Regulations. Modified versions of the agreement are used by countries in Southeast Asia and South America [7]. The ADR Agreement also applies to internal transport in European Union countries through Council Directive 2008/68 / EC [7].

\subsection{In Africa}

According to the research by Adewole [20] and Adewole and Struthers [21], road transport is the most dominant mode of motorized transport in Africa, accounting for $80 \%$ of the goods traffic and $90 \%$ of the passenger traffic on the continent [22]. Several international and bilateral agreements and protocols simplifying and harmonizing interstate trade and transport have been signed between Central, Southern, Eastern, Western, and Northern African states. These instruments cover the general cargo transportation by road and multimodal, the regulations of the TDG, the rules of the road and civil aviation, the maritime cooperation, the common insurance schemes for vehicles, the common border posts and transport corridor management mechanisms [22].

The findings of the recent scientific publications (since 2010) on road freight transport, which reviews the entire African continent such as Foster \& Briceno-Garmendia [23], Adewole [20], Jedwab and Storeygard [24] on the one hand and those detailing sub-Saharan Africa (which includes Central, Southern, Eastern, and Western Africa) such as Christie et al. [25], Runji [26] and Calderon et al. [27] on the other, reveal inadequate infrastructural facilities, lack of a continent-wide regulatory framework, lack of political will and limited application of technology.

\subsubsection{In Central Africa}

Central Africa, which includes Cameroon, Gabon, Congo, Chad, the Central African Republic and Equatorial Guinea, has made considerable efforts to unify commercial and transport law. Its conventions codify the practices applicable to the relations between carriers and shippers, which are private law relationships. Many of the other agreements deal with the public administration of Transport Corridors, police, customs and other regimes [28]. On July $5^{\text {th }}$, 1996, the members of the Council of Heads of State of the Central African Customs and Economic Union (or UDEAC from its name in French, Union Douanière et Économique de l'Afrique Centrale) replaced since 1994 by the Economic and Monetary Community of Central Africa (or CEMAC from its name in French: Communauté Économique et Monétaire de l'Afrique Centrale) defined a framework for road transport of goods in the sub-region (Act 4/96-UDEAC-611-EC-3). This framework gave rise to the inter-state Convention for the Road Transport of Miscellaneous Goods (or CIETRMD from its name in French: Convention Inter-États de Transport Routier de Marchandises Diverses) [28]. On June 25, 1999, the Council of Ministers of CEMAC promulgated the regulation of TDG signed in Malabo in 1999 and which is applicable in all the States of the Community [28]. In the field of transport infrastructure, Member States have agreed to promote a policy of transport coordination and infrastructure standardization [28].

\subsubsection{In East African Community}

The East African Community, which includes Burundi, Comoros, Djibouti, Eritrea, Ethiopia, Kenya, Rwanda, Seychelles, Somalia, Sudan, South Sudan, Tanzania and Uganda, signed on October 7, 2007 in Nairobi, Kenya, a new Agreement: The Northern Corridor Transit and Transport Agreement (NCTTA) [29] which entered into force on December 6, 2012 and which repeals the old one signed in Nairobi on November 8, 1985. It is a multilateral treaty to facilitate transit cargo between the Kenyan port of Mombasa 
and the hinterland of Member States namely Burundi, Democratic Republic of Congo, Rwanda, Uganda and South Sudan. The NCTTA Agreement aims to promote the use of the Northern Corridor, as defined, as the most efficient route for the land transport of goods between the States Parties to the Agreement. The Contracting States have therefore agreed to grant each other the right of transit through their territory and to provide the infrastructure, equipment, services, regulations and procedures for this purpose on the basis of the principles of reciprocity and non-discrimination [30]. In accordance with Article 41 (b) of the NCTTA Agreement, dangerous goods carried in transit through the territories of any contracting party or carried within the territories of the contracting parties in the case of interstate traffic shall be handled in accordance with the provisions specified in protocol $\mathrm{N}^{\circ} 10$ (Ten) of this agreement on handling of dangerous goods [30, 31] which therefore refers to the relevant international standards, including the recommendations of the UN Committee of Experts on the TDG; the Regulations for the safe transport of radioactive material of the International Atomic Energy Agency (IAEA); the provisions concerning the TDG included in the International Convention for the Safety of Life at Sea (SOLAS) and the ICAO Technical Instructions [32].

In the field of infrastructure development and in accordance with Article 4 of the NCTTA Agreement, the contracting parties undertake to cooperate for the purpose of investment planning, the commissioning of transport infrastructure, the equipment and transit, to jointly solicit funding to implement the project, to harmonize their standards and procedures for the design, construction, operation and maintenance of infrastructure and to encourage the private sector to participate in the financing of construction and maintenance of infrastructure and transport facilities [31].

\subsubsection{In Southern Africa}

Southern Africa includes Angola, Botswana, Lesotho, Malawi, Mauritius, Mozambique, Namibia, São Tomé and Príncipe, South Africa, Swaziland, Zambia and Zimbabwe. Member States agreed to facilitate the movement of goods and passengers by encouraging the development of a strong and competitive road transport industry and by developing harmonized systems for the enforcement of transport law [33]. The Southern African Development Community (SADC) and East African community (EAC) are closely associated through some instruments including the Southern African Customs Union (SACU), the Common Market for Eastern and Southern Africa (COMESA), the Interregional Cooperation and Integration Instrument, also known as Tripartite Free Trade Area (TFTA).

The Tripartite aims at strengthening and deepening the economic integration of the southern and eastern regions in order to avoid the problems of overlap due to the fact that Member States belonged to several Regional Economic Communities (RECs). Although RECs have already harmonized some programs, others remain fragmented, and some do not even cover the entire tripartite region. To remedy this situation, the Memorandum of Understanding on interregional cooperation and integration has been prepared for members of Tripartite. This Protocol is undated, but it is likely that it was signed at the June 2011 meeting. The Transport of Dangerous Goods is regulated by the NCTTA East African Agreement [33].

\subsubsection{In West Africa}

West Africa has a long history of cooperation between States in the field of transport. It is made up of two sub-regional groups: i) the Economic Community of West African States (ECOWAS) and ii) the West African Economic and Monetary Union (WAEMU). The members of ECOWAS are Benin, Burkina Faso, Côte d'Ivoire, The Gambia, Ghana, Guinea, Liberia, Mali, Niger, Nigeria, Senegal, Sierra Leone and Togo. Guinea-Bissau joined ECOWAS in 1975 and Cape Verde in 1979. Mauritania was formerly a member but withdrew in 2000 [34].

After the return of Morocco to the African Union in January 2017 after 33 years of absence, Morocco presented its candidacy in February 2017 to ECOWAS which has given its agreement in principle during the Monrovia Summit in June 2017. However, at the next Summit in December 2017, ECOWAS set up a Committee of Heads of State and Government composed of Togo, Côte d'Ivoire, Ghana, Guinea and Nigeria, to adopt the terms of reference and oversee the indepth study of the implications of Morocco's accession.

The West African Economic and Monetary Union (WAEMU) member states are Benin, Burkina Faso, Côte d'Ivoire, Guinea Bissau, Mali, Niger, Senegal and Togo. ECOWAS transport policy is set out in Chapter VIII of the 1975 Lagos Treaty and Articles 40 to 44 and Article 32 of Chapter VII of the 1993 Cotonou Treaty [34]. In addition to the protocol $\mathrm{N}^{\circ}$ II which presents the sectoral policies of WAEMU, specific guidelines and recommendations are published for each mode of transport [35]. Dangerous goods are managed by Protocol $\mathrm{N}^{\circ} 6[35,36]$ which deals with handling, storage and transport.

\subsubsection{In North Africa}

In North Africa (including Algeria, Egypt, Libya, Mauritania, Morocco and Tunisia), many initiatives taken since independence to launch a dynamic of economic integration such as the Arab Maghreb Union (1989), the Greater Arab Free Trade Area (GAFTA - 1996), the Agadir Agreement (2001) and the bilateral conventions, are unsatisfactory, especially since intra-regional trade does not exceed $4 \%$ of the total foreign trade of the countries of the sub-region [37]

Increasing the level of performance of these countries in transport and trade requires adherence to the main international conventions (Nine Conventions) governing transport, transit and trade facilitation, as shown in Table 1. Morocco has acceded to almost all of these conventions (7 out of 9). Agreements acceded to by Morocco include: The Convention on International Transport of Goods Under Cover or TIR Convention (TIR from its name in French, Transports Internationaux Routiers), the Convention on the Contract for the International Carriage of Goods by Road or simply CMR Convention (CMR stands for 'Convention Relative au Contrat de Transport International de Marchandises par la Route'), the Agreement on the International Carriage of Perishable Foodstuffs and on the Special Equipment to be used for such Carriage, known as the ATP agreement (after its French initials), the Revised Kyoto Convention, the Convention on Road Traffic, the Vienna Convention on Road Signs and Signals and the ADR Agreement. Tunisia followed the same path of development by adopting seven conventions (TIR Convention, CMR Convention, ATP Convention, Geneva Convention on the Harmonization of Frontier Procedures, Convention on Road Traffic, Convention on Road Signs and Signals, ADR Agreement); Libya has not signed any of these 
conventions, while Algeria has signed three (TIR Convention, Revised Kyoto Convention and the Customs Convention on the Temporary Importation of Commercial Road Vehicles of 1956). Egypt signed only the revised Kyoto Convention and Mauritania only signed the CMR Convention [37].

Table 1. Summary of the main international conventions governing transport, transit and trade facilitation in North Africa

\begin{tabular}{|c|c|c|c|c|c|c|}
\hline International conventions & 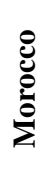 & 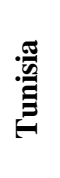 & $\frac{\pi}{2}$ & $\sum_{\substack{00 \\
0}}^{\overrightarrow{0}}$ & 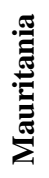 & 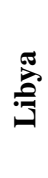 \\
\hline TIR Convention & $\mathrm{X}$ & $\mathrm{X}$ & $\mathrm{X}$ & & & \\
\hline CMR Convention & $\mathrm{X}$ & $\mathrm{X}$ & & & $\mathrm{X}$ & \\
\hline ATP agreement & $\mathrm{X}$ & $\mathrm{X}$ & & & & \\
\hline Revised Kyoto Convention & $\mathrm{X}$ & & $X$ & $X$ & & \\
\hline Convention on Road Traffic & $\mathrm{X}$ & $\mathrm{X}$ & & & & \\
\hline $\begin{array}{l}\text { Vienna Convention on Road } \\
\text { Signs and Signals }\end{array}$ & $\mathrm{X}$ & $X$ & & & & \\
\hline ADR Agreement & $\mathrm{X}$ & $\mathrm{X}$ & & & & \\
\hline $\begin{array}{l}\text { Geneva Convention on the } \\
\text { Harmonization of Frontier } \\
\text { Procedures }\end{array}$ & & $\mathrm{X}$ & & & & \\
\hline $\begin{array}{c}\text { Customs Convention on the } \\
\text { Temporary Importation of } \\
\text { Commercial Road Vehicles } \\
\text { of } 1956\end{array}$ & & & $\mathrm{X}$ & & & \\
\hline
\end{tabular}

In Morocco. Road transport provides $90 \%$ of people's mobility and $75 \%$ of the flow of goods excluding phosphate [38]. The national road network has a total length of $57,334 \mathrm{~km}$. Highways $1,800 \mathrm{~km}$ and 1,124 km of expressways [39]. Road traffic on the entire road or highway network was evaluated in 2017 to 102.33 million vehicle kilometers per day against 99.35 in 2016, an increase of $3.00 \%$. According to the Moroccan Ministry of Transport and Logistics, traffic accidents cause an annual average of nearly 3,500 deaths and 12,000 serious injuries, an average of 10 deaths and 33 serious injuries per day. The professional transport represents $8.7 \%$ of these fatalities [39]. All these statistics have a direct influence on the performance of the transport of dangerous goods.

The Moroccan kingdom acceded to the ADR Agreement on May 11, 2001, ratified it on June 11, 2001 and published it in the Official Gazette by Dahir $N^{\circ} 1.96 .3$ on June 19, 2003 [40]. The provisions of this agreement apply to vehicles transporting dangerous goods to or from abroad [41]. In order to improve structures and activities related to this type of transport, a twinning project between Morocco and the European Union within the framework of the "Succeed the Advanced Status" program was launched to secure the TDG by road on the basis of the international ADR regulatory framework, the requirements of the acquis and European good practice. The beneficiary administration of this project is the Ministry of Equipment, Transport and Logistics (METL), represented by the Department of Road Transportation Safety in charge of management and the implementation of this initiative [41].

In 2011, Morocco has adopted the Law $N^{\circ} 30.05$ on the transport of dangerous goods promulgated by the Dahir $\mathrm{N}^{\circ} 1.11 .37$ of June 2, 2011, published in the Official Gazette $\mathrm{N}^{\circ} 5956$ of June 30, 2011 [42], which has allowed it to embark on the reinforcement of its road safety, the liberalization of road transport and the professionalization of the carriers introduced in the country by the great reform of the law of the road transport of goods enshrined by the Law $\mathrm{N}^{\circ} 16-99$ of March 16, 2000, published in the Official Gazette $\mathrm{N}^{\circ} 4778$ of March 16, 2000, entered into force on March 13, 2003 [41] and designed (i) to retain professionalism as a criterion for access to the road haulage market, (ii) to open the market for the carriage of goods to fair competition by the liberalization of the pricing system and (iii) to serve as basis for a whole series of measures in this direction, including the abolition of accreditation and the abolition of quantitative restrictions on services offered, the redefinition of relations between shippers and carriers through the abolition of the charter monopoly or further, the increased professionalization of the sector through the introduction of qualitative criteria for access to for-hire freight trades. Indeed, the Law $\mathrm{N}^{\circ} 30-05$ of June 2, 2011 governs the activities of the road TDG by defining the specific rules applicable to this activity, such as the conditions of classification, packing, loading, unloading and filling of these goods and their shipment, including signage, labeling, placarding, marking and documents to accompany shipments [41]. The provisions of this law also determine the conditions of use of vehicles, tanks, containers and other equipment, apply to all transport carried out on the Moroccan territory for occasional or regular dangerous goods by road and to any person performing this type of transport. They also concern manufacturers, shippers, handlers, consignees of dangerous goods and users of packaging, tanks, vehicles and containers used for the transport of dangerous goods by road [41]. On the other hand, the text stipulates a special technical inspection for vehicles and all dangerous goods, just as it insists on the requirement of specialized training for drivers [41].

Finally, the Law $\mathrm{N}^{\circ} 30-05$ has two important effects. On the one hand, it expressly repeals or removes any value of opposability (in Article 41) from certain texts, such as the Dahir of 30th of December, 1927 concerning the transport of hydrocarbons, or the Dahir of 2nd of March, 1938 regulating the handling and transport by land of dangerous substances, combustible materials, flammable liquids (other than hydrocarbons and liquid fuels). On the other hand, the law calls for the revision of previous texts, such as the one concerning the distinctive marks to be carried by vehicles carrying dangerous goods by road (Decree of the Minister of Transport $\mathrm{N}^{\circ} 2109-93$ of 31 st of January, 1995) [41]. It should be noted that the Moroccan Constitution of July 1, 2011 enshrines, in its preamble, the principle of the primacy of international conventions duly ratified by the Kingdom on national law. It follows that Morocco undertakes to harmonize the relevant provisions of its legislation to make it compatible, if not, in conformity with its international commitments [41].

In addition to the ratification of the ADR agreement, road transport in Morocco is governed by several other international conventions, namely: (i) The CMR Convention of May 19, 1956 (Morocco acceded to it on the 23rd of February, 1995). (ii) The TIR Convention of 1975 (Entered into force in Morocco on 30th of September, 1983), and (iii) the ATP Agreement of 1970 (Ratified by Morocco on October 22, 1980 and entered into force on March 5, 1988). With regard to bilateral agreements, Morocco has concluded several agreements on international road transport of passengers and goods. These agreements include the setting up of a quota of bilateral authorizations, cooperation and exceptional transport [43].

In the field of infrastructure, Morocco currently has a strategy in the short and medium term to increase the density of the national network in response to the imperatives of 
national economic activity and its increasing openness to the world market. In fact, investments granted to highway network increased 35-fold between 1993 and 2009 [44]. This strong growth is part of a national network development plan accompanied by regulatory measures for the transport of goods and passengers in order to increase the volume and interregional traffic. The $28^{\text {th }}$ national transport and logistics plan adopted in 2010 and approved by the King Mohammed VI is in line with this vision [44].

In accordance with the Global Plan of Action for the Decade of Action for Road Safety 2011-2020 and the 2017-2026 national road safety strategy, Morocco has initiated strategies, normative and institutional reforms for good governance of road safety with a view to preserve goods, people and environment [45].

\section{PERSPECTIVES}

Most studies conducted by researchers on transport and road infrastructure in Africa between 2010 and 2019, such as Adewole [20], Foster and Briceno-Garmendia [23], Jedwab and Storeygard [24], recommend that adequate freight transport facilities and regulatory reforms are essential to logistical infrastructure development in Africa. Among the countries of Africa, only those in the North are declining in the area of the TDG, except for Morocco and Tunisia which have adopted ADR Agreement. The Moroccan MELT carried out a study which defined a road map outlining the strategy to be adopted in the road sector by 2035 [39].

Despite these efforts, considerable deterioration of the road network was noted during the period 2004 to 2012 [46], which considerably affected the comfort and safety conditions of road users. In addition, informal transport continues to hinder the development of the sector by escaping social and fiscal regulations [47].

Studies of road problems in Morocco are not sufficiently addressed by researchers. The MELT and the National Committee for the Prevention of Traffic Accidents are the only source of data related to road safety, hence the need to create research centers and to integrate road safety into university courses which will lead to the accumulation of research and studies on road safety issues [45].

From a road safety perspective, the work of De-Marcellis et al., [48], in Quebec has shown that the organizational safety practices of TDG have a significant impact on accident severity on vulnerable areas and individuals, hence the interest in diagnosing the current level of safety culture in this sector of activity in order to act with public and private stakeholders on the risks and opportunities for its improvement.

A recent study for TDG industries was conducted in the same context by Sabar et al., [49], and was then generalized to other sectors of activity related to TDG in a life-cycle perspective (chemical industry, chemical trading companies and finally waste collection and treatment companies). This study is innovative in the sense that, to our knowledge, no survey relating to this research theme has been carried out at the Moroccan or African scale. It is also innovative in that it offers dangerous goods carriers practical tools to identify the strengths and weaknesses of their organizations and provides relevant data to occupational physicians and the public authorities concerned which will serve as a basis for future research work. The realization of this diagnosis has not been possible and effective without having reviewed the regulatory and institutional context at the international, African and Moroccan levels on the one hand, and the safety culture on the other. The results of this study can be generalized at the African and international levels.

\section{CONCLUSION}

The findings of the four sub-regions of Africa (West Africa, Central Africa, East Africa and Southern Africa) show that they are lagging behind in meeting the requirements of ADR, while for North Africa, Morocco, given its advanced status with the European Union, its political stability and its geographical position, stands out in terms of compliance with this agreement compared to the other members of this geographical area.

The commonalities that need to be improved for African states to meet international standards can be summarized, on the one hand, for the public sector, in the synergy between the different state institutions, the applicability of legislation and the association of responsibility to accountability. On the other hand, for the private sector, the perspectives presented by some studies relating to the diagnosis of the level of maturity in safety culture in the TDG sector and the determination of the Moroccan safety culture profile are promising and deserve deep reflection on this subject, which will enable this sector to detect its strengths and weaknesses in order to then address them in a perspective of continuous improvement.

\section{ACKNOWLEDGMENT}

The authors would like to thank Mr Xavier Huillard, Chairman and Chief Executive Officer of VINCI, Mr Jérôme Stubler, President of VINCI Construction and Mr Driss EL Rhazi, Chief Executive Officer of SOGEA MAROC for their leadership and commitment to improve health and safety at work in Africa in general and Morocco in particular.

\section{REFERENCES}

[1] French Federation of Road Transport. (2018). Activity report 2018 [Internet]. Available from: http://www.fntr.fr/espace-

documentaire/publications/rapport-activite-annuel-fntr, accessed on 31 Sep. 2019.

[2] European Commission. (2019). Annual Road Freight Transport of Dangerous Goods, by Type of Dangerous Goods and Broken Down by Activity [Internet]. Eurostat data base. Available from: https://ec.europa.eu/eurostat/web/products-

datasets/product?code=road_go_ta_dg, accessed on 27 Sep. 2019.

[3] Nyquist, M.C. (2015). Transportation of hazardous goods: A multi-stakeholder analysis for improved efficiency and safety through information sharing. Paper presented at NOFOMA 2015 - University of Molde, Norway. Available from: https://www.researchgate.net/publication/307569439_T ransportation_of_dangerous_goods_A_multiple_stakeh older_analysis_for_improved_efficiency_and_safety_th rough_information_sharing/citations\#fullTextFileConte nt, accessed on 31 Sep. 2019. 
[4] Conca, A., Ridella, C., Sapori, E. (2016). A risk assessment for road transportation of dangerous goods: A routing. Transportation Research Procedia, 14: 28902899. https://doi.org/10.1016/j.trpro.2016.05.407

[5] Ebrahimi, H., Tadic, M., (2018). Optimization of dangerous goods transport in urban zone. Decision Making: Applications in Management and Engineering, 1(2):

$131-152$ https://doi.org/10.31181/dmame1802138e

[6] World Health Organization. (2019). Guidance on Regulations for the Transport of Infectious Substances 2019 - 2020. World Health Organization, pp. 7-10. Licence: CC BY-NC-SA 3.0 IGO.

[7] United Nations Economic Commission for Europe. (2019). European agreement concerning the international carriage of dangerous goods by road (ADR). United Nations, New York and Geneva, 1(275): 5-13 https://doi.org/10.18356/77c830aa-fr

[8] United Nations Economic Commission for Europe. (2019). European agreement concerning the international carriage of dangerous goods by inland waterways (ADN). United Nations, New York and Geneva, 1(276): 5-62. https://doi.org/10.18356/868dfa06-en

[9] Intergovernmental Organization for International Carriage by Rail. (2017). Convention Concerning International Carriage by Rail (COTIF) Appendix C Regulations Concerning the International Carriage of Dangerous Goods by Rail (RID). pp. PI1-PI77.

[10] International Maritime Organization. (2018). International Maritime Dangerous Goods (IMDG) Code - Incorporating Amendment 39-18, IMO Publishing, Copyright (CIMO, 2018, London, United Kingdom.

[11] International Civil Aviation Organization. (2018). Technical Instructions for the Safe Transport of Dangerous Goods by Air, ICAO Doc 9284, Copyright (C) ICAO, 2018, Montréal, Quebec, Canada, pp. PI1-PI7.

[12] United Nations Economic Commission for Europe. (2017). Globally Harmonized System of Classification and Labelling of Chemicals (GHS), Seventh revised edition, Copyright (C) United Nations, 2017, New York and Geneva, Part I, pp. PI3-PI35.

[13] United Nations. (2019). UN Recommendations on the Transport of Dangerous Goods - Model Regulations, Twenty-first revised edition, Copyright (C) United Nations, 2019, New York and Geneva, 1(Part I): PI22PI48. https://doi.org/10.18356/7c03b465-en

[14] Erkut, E., Verter, V. (1995). Hazardous materials logistics. Facility Location: A Survey of Applications and Methods ed. Z. Drezner, Springer-Verlag, New York Google Scholar, pp. 467-506.

[15] Erkut, E., Tjandra, S.A., Verter, V. (2007). Chapter 9 Hazardous Materials Transportation. Handbooks in Operations Research and Management Science, 14: 539621. https://doi.org/10.1016/S0927-0507(06)14009-8

[16] Erol, S., Yilmaz, Z. (2016). A literature survey for hazardous materials transportation. In: Dima, I., OcalirAkunal, E.V. (Eds.), Using decision support systems for transportation planning efficiency. IGI Global, pp. 371393. https://doi.org/10.4018/978-1-4666-9562-7.ch058

[17] Holeczek, N. (2019). Hazardous materials truck transportation problems: A classification and state of the art literature review. Transportation Research, 69: 305328. http://dx.doi.org/10.1016/j.trd.2019.02.010

[18] Imeri, A., Khadraoui, D., Khadraoui, A. (2017). A conceptual and technical approach for transportation of dangerous goods in compliance with regulatory framework. Journal of Software, 12(9): 708-721. https://doi.org/10.17706/jsw.12.9.708-721

[19] Russo, F., Rindone, C. (2014). Risk occurrence measures for dangerous goods transport on a road network. Safety and Security Engineering, 134: 529-539. http://dx.doi.org/10.2495/SAFE130471

[20] Adewole, A. (2018). Logistics and supply chain infrastructure development in Africa. Logistics and Global Value Chains in Africa, 17-43. https://doi.org/10.1007/978-3-319-77652-1_2

[21] Adewole, A., Struthers, J.J. (2019). Logistics and global value chains in Africa. Palgrave Studies of Sustainable Business in Africa. https://doi.org/10.1007/978-3-31977652-1

[22] United Nations Economic Commission for Africa. (2010). African Review Report on Transport (Summary). Copyright (C) UN. ECA, Addis Ababa, pp. 1-28.

[23] Foster, V., Briceno-Garmendia, C. (2010) Africa's Infrastructure: A Time for Transformation. Africa Development Forum. Copyright (C) World Bank, License: CC BY 3.0 IGO, Washington DC, pp. 210-226. https://doi.org/10.1596/978-0-8213-8041-3

[24] Jedwab, R., Storeygard, A. (2019). Economic and political factors in infrastructure investment: Evidence from railroads and roads in Africa 1960-2015. Economic History of Developing Regions, 34(2): 156-208. https://doi.org/10.1080/20780389.2019.1627190

[25] Christie, A., Smith, D., Conroy, K. (2013). Transport Governance Indicators in Sub-Saharan Africa. SubSaharan Africa Transport Policy Program (SSATP), Copyright (C) World Bank, License: CC BY 3.0 IGO, Washington DC, 95: 5-61.

[26] Runji, J. (2015). Africa Transport Policies Performance Review: The Need for More Robust Transport Policies. Sub-Saharan Africa Transport Policy Program (SSATP), Copyright (C) World Bank, License: CC BY 3.0 IGO, Washington DC, 103: 5-40.

[27] Calderon, C., Cantu, C., Chuhan-Pole, P. (2018). Infrastructure development in Sub-Saharan Africa: A scorecard. World Bank Policy Research Working Paper, 8425: 4-41.

[28] Grosdidier de Matons, J. (2014). A review of international legal instruments: Facilitation of transport and trade in Africa. Second edition (English), SubSaharan Africa Transport Policy Program (SSATP), (C) World Bank, License: CC BY 3.0 IGO, Washington, DC, Part IV: IV107-IV138.

[29] The Northern Corridor Transit and Transport Coordination Authority. (2007). Northern Corridor Transit and Transport Agreement (English). TTCANC[Internet]. 06Oct.2007.Available from: http://www.ttcanc.org/documents/the_nothern_corridor _transit_agreement.pdf, accessed on: 29 Jul. 2019.

[30] Grosdidier de Matons, J. (2014). A Review of International Legal Instruments: Facilitation of Transport and Trade in Africa. Second edition (English), SubSaharan Africa Transport Policy Program (SSATP), (C) World Bank, License: CC BY 3.0 IGO, Washington, DC, Part V: V143-V165.

[31] Grosdidier de Matons, J. (2014). New Northern Corridor Transit \& Transport Agreement (Nairobi, 2007). In: Grosdidier de Matons, J. (ed.), A Review of International 
Legal Instruments: Facilitation of Transport and Trade in Africa. Second edition (English), Sub-Saharan Africa Transport Policy Program (SSATP), (C) World Bank, License: CC BY 3.0 IGO, Washington, DC, pp. 255-256.

[32] Grosdidier de Matons, J. (2014). Protocol no 10 Handling of Dangerous Goods. In: Grosdidier de Matons, J. (ed.), A Review of International Legal Instruments: Facilitation of Transport and Trade in Africa. Second edition (English), Sub-Saharan Africa Transport Policy Program (SSATP), (C) World Bank, License: CC BY 3.0 IGO, Washington, DC, pp. 255-256.

[33] Grosdidier de Matons, J. (2014). A Review of International Legal Instruments: Facilitation of Transport and Trade in Africa. Second edition (English), SubSaharan Africa Transport Policy Program (SSATP), (C) World Bank, License: CC BY 3.0 IGO, Washington, DC, Part VI: VI167-VI201.

[34] Grosdidier de Matons, J. (2014). A Review of International Legal Instruments: Facilitation of Transport and Trade in Africa. Second edition (English), SubSaharan Africa Transport Policy Program (SSATP), (C) World Bank, License: CC BY 3.0 IGO, Washington, DC, Part VII: VII203-VII242.

[35] N' Guessan, N. (2003). Improvement of Transit Transport in West Africa [FRENCH]. United Nations Conference on Trade and Development (UNCTAD), UCTAD [Internet], pp. 5-45. Available from: https://unctad.org/en/docs/ldc20032_en.pdf, accessed on 26 Sep. 2019.

[36] Grosdidier de Matons, J. (2014). Protocol no. 6 Transport by Road of Goods in Transit. In: Grosdidier de Matons, J. (ed.), A Review of International Legal Instruments: Facilitation of Transport and Trade in Africa. Second edition (English), Sub-Saharan Africa Transport Policy Program (SSATP), (C) World Bank, License: CC BY 3.0 IGO, Washington, DC, pp. 255-256. Available

from:

https://www.ssatp.org/sites/ssatp/files/legal-

instruments-en/Chapters/SSATP-Legal\%20Review.pdf, accessed on 29 Jul. 2019.

[37] United Nations. (2015). International Transport and Trade Facilitation in North Africa, Economic Commission for Africa-Office for North Africa (ECANA). () ECA-NA, pp. 48-77. Available from: https://repository.uneca.org/bitstream/handle/10855/227 10/b11542858.pdf?sequence $=1$, accessed on $29 \mathrm{Jul}$. 2019.

[38] El Khayat, M. (2018). Le droit du transport multimodal de marchandise au Maroc (French). Revue Espace Géographique et Société Marocaine (French), 24-25: 4445.

[39] Ministry of Equipment, Transport, Logistics and Water. (2019). Road sector, METL[Internet]. Available from: http://www.equipement.gov.ma/Infrastructures-

Routieres/Infrastructuresautoroutieres/Pages/Infrastructures-autoroutieres.aspx, accessed on 30 Sep. 2019.

[40] Mharzi, H. (2016). Supply chain durable au Maroc : Etat des lieux, motivations et obstacles (French). Strategy Management Logistics, SMALOGresearch, ISSN: 2509-
0186, $\mathrm{p}$ 3. Available from: https://revues.imist.ma/index.php?journal=MLS\&page= article\&op=view \&path $\% 5 \mathrm{~B} \% 5 \mathrm{D}=6812$, accessed on 30 Sep. 2019.

[41] European Union. (2016). Program Succeeding Advanced Status: Securing the Transport of Dangerous Goods by Road on the Basis of the International Regulatory Framework ADR, Kingdom of Morocco, Ares 318041, Twinning Record MA/13/ENPI/TP/01/16/(MA/44), pp. 1-43. Available from: https://www.esteri.it/mae/resource/garegemellaggi/2016 /07/ma_13_enpi_tp_01_16_ma_44.pdf, accessed on 30 Sep. 2019.

[42] Official Gazette. (2011). Dahir n ${ }^{\circ} .11 .37$ of June 2, 2011 (French), Kingdom of Morocco, no.5956. Available from: http://adala.justice.gov.ma/production/html/Fr/173916.h tm, accessed on 29 Jul. 2019

[43] Ministry of Economy and Finance. (2010). Bilateral Agreements Between Morocco and its Foreign Partners in International Road Transport (French), Customs and excise Administration, pp. 1-2. Available from: http://www.douane.gov.ma/web/guest/nos-publications, accessed on 29 Jul. 2019.

[44] Oulmakki, O. (2015). Impact of transport infrastructure on economic growth: the case of Morocco. Economies and finances (French). Montpellier University, pp. 132138.

[45] AHSAIN, S. (2018). Public policies on road safety in morocco (French). Revue des Etudes et Recherches en Logistique et Développement (RERLED), (French), 1(6): 79-102.

[46] Ministry of Economy and Finance. (2013). The Freight Transport Sector: Constraints and Ways of Reform (French). Department of Economic Studies and Financial Forecast, Kingdom of Morocco, pp. 10-11. Available from:

https://www.finances.gov.ma/Docs/depf/2013/4193_sec teur_transport_mdises_03_2013.pdf, accessed on: 29 Jul. 2019.

[47] Ministry of Equipment, Transport, Logistics and Water. (2018). Performance Project (Arabic), Morocco, pp. 1-56 Available from: http://lof.finances.gov.ma/fr/budget/projet-deperformance-2018, accessed on 29 Jul. 2019.

[48] De Marcellis-Warin, N., Peignier, I., and Trépanier, M., (2012). Organizational Safety Practices at Hazardous Material Motor Carriers in Québec. Institut de recherche Robert-Sauvé en santé et en sécurité du travail (IRSST in French), Montréal, Québec. Available from: https://www.irsst.qc.ca/publications-etoutils/publication/i/100669/n/les-pratiquesorganisationnelles-de-securite-chez-les-transporteursroutiers-de-matieres-dangereuses-au-quebec-r751/redirected/1, accessed on 13 Oct. 2019.

[49] Sabar, M., El hammoumi, M., Ech-Chelfi, W., Bakraouy, H., Fadil, M. (2019). Diagnosis of the safety culture of carriers of dangerous goods by road: A case study of Morocco. International Journal of Engineering Research and Technology, 12(12): 2254-2261. 